\title{
Les techniques de production des saumures en Europe et en Chine au Moyen Âge
}

\section{Ying Miao}

\section{(2) OpenEdition}

1 Journals

Édition électronique

URL : https://journals.openedition.org/tc/661

DOI : $10.4000 /$ tc. 661

ISSN : 1952-420X

Éditeur

Éditions de l'EHESS

\section{Édition imprimée}

Date de publication : 1 mai 1993

ISSN : 0248-6016

\section{Référence électronique}

Ying Miao, "Les techniques de production des saumures en Europe et en Chine au Moyen Âge », Techniques \& Culture [En ligne], 19 | 1993, mis en ligne le 10 janvier 2006, consulté le 29 septembre 2022. URL : http://journals.openedition.org/tc/661 ; DOI : https://doi.org/10.4000/tc.661

Ce document a été généré automatiquement le 29 septembre 2022.

Tous droits réservés 
Les techniques de production des saumures en Europe et en Chine au Moyen Âge

Ying Miao 